CATALAN REVIEW

Catalan Review

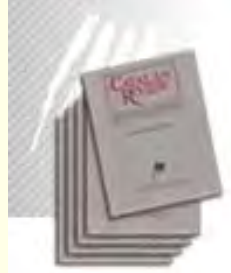

You are accessing the Digital Archive of the Catalan Review Journal.

By accessing and/or using this Digital Archive, you accept and agree to abide by the Terms and Conditions of Use available at http://www.nacs-

catalanstudies.org/catalan_review.html

Catalan Review is the premier international scholarly journal devoted to all aspects of Catalan culture. By Catalan culture is understood all manifestations of intellectual and artistic life produced in the Catalan language or in the geographical areas where Catalan is spoken. Catalan Review has been in publication since 1986 .
NORTH

AMERICAN

CATALAN

SOCIETY
Esteu accedint a l'Arxiu Digital del Catalan Review

A l' accedir i / o utilitzar aquest Arxiu Digital, vostè accepta i es compromet a complir els termes i condicions d'ús disponibles a http://www.nacs-

catalanstudies.org/catalan_review.html

Catalan Review és la primera revista internacional dedicada a tots els aspectes de la cultura catalana. Per la cultura catalana s'entén totes les manifestacions de la vida intel lectual i artística produïda en llengua catalana o en les zones geogràfiques on es parla català. Catalan Review es publica des de 1986.

\title{
Icària, Icària: from Utopian Dreams to Anarchist Reality Joan J. Gilabert
}

Catalan Review, Vol. II, number 1 (1987), p. 111-121 


\title{
ICÀRIA, ICÀRIA: \\ FROM UTOPIAN DREAMS TO ANARCHIST REALITY
}

\author{
JOAN J. GILABERT
}

-Senyor, vull viure, voldria quedar-me.

(...) "-No barreu les tanques,

vull dir la vida mentre em quedi alè.

Si no puc dir-la, demano tornar-hi

- que no puc creure en cap cel més serè."

(Joan Salvat-Papasseit, La Mort del Just)

The roots of modern Catalan literature must be sought in the Romantic period. We have repeatedly insisted that the Renai$x e n \xi a$ is the direct result of the economic nationalism that was already evident in our society at the beginning of the nineteenth century. ${ }^{1}$ It was not a quirk of fate that Bonaventura Carles Aribau first read his ode "La Pàtria" in 1833, in Madrid, at the home of the Catalan banker, Gaspar de la Remisa.

Romanticism was the beginning of the Catalan Renaixença, which thus acquired from the outset a conservative and homespun character. Works such as l'Atlantida and La Febre d'Or attempted to create myths of Catalanicity well matched to the economic concerns and the jocs florals - cultural interests of the magnates, who had rejected the tired and fossilized Castile

${ }^{1}$ Joan Gilabert, Narcís Oller (Barcelona: Marte, 1977); also in Joan Gilabert, "La febre d'or de Narcis Oller i Miau de Galdós: dues visions de la realitat social a l'Espanya del segle XIX", Estudis de Llengua, Literatura i Cultura Catalanes; Actes del Primer Congrés d'Estudis Catalans a Nord-Amèrica (Urbana, Illinois), (Montserrat: Publicacions de l'Abadia de Montserrat, 1979), 241-254. 
of the nineteenth century. They had opposed it with a Catalonia swelling with common sense, unity, harmony, and national unity, a progressive Catalonia disposed, above all, to conquer the Castilian state. Narcís Oller, our greatest novelist of the nineteenth century, affirms:

Si, senyor alcalde, nosaltres som una força; una força invencible, incontrastable. En aquest temps d'escepticisme i de negació, som una força invencible perquè tenim "un ideal generós, gran, indispensable al progrés i engrandiment dels pobles."2

This pseudo-romantic idealism of Catalanicity converted a possible national revolution of an entire people into a bourgeois revolution that failed. ${ }^{3}$ These ancestors of senyor Esteve took seriously that which Sir Walter Scott's doubted. That is, that Albion's society and culture were not exclusively the product of the tradition of knighthood and good sense, but rather that cultural values were open to everything and everyone. Unfortunately, Catalan Romanticism never had a Lord Byron, a Hölderlin or a Victor Hugo, due to socio-economic necessities, narrowmindedness, or perhaps a simple lack of imagination. Catalan culture was reduced to certain mythical formulae of the literature of jocs florals and "àpats de germanor". From the time of the jocs florals to the era of the League, Catalan culture was considered a solid, invincible force as Oller described it. The Tragic Week of 1909 and the leftist, populist movement at

${ }^{2}$ Address by Narcis Oller to the mayor of Barcelona, Rius i Taulet, at the World's Fair of Barcelona (1888). Cited by Narcís Oller, Memòries literàries: Història dels meus llibres (Barcelona: Aedos, 1962), 121.

3 "La història del nacionalisme català és la història d'una revolució burgesa frustrada. El seu fracàs és una de les causes fonamentals del nostre endarreriment econòmic i politic." Jordi Solé-Tura, Catalanisme i revolució burgesa (Barcelona: Edicions 62, 1967), 7. 
the beginning of the century undid for all time the ideological bases of this Catalonia of "flaming tombs". Valentí Almirall roundly stated, "Tots els que en parlar del nostre país no toleren més que lloances i grandeses poden girar full i passar per alt aquest capitol"4

Catalan Romanticism returned to its classical literary past, approaching it with bourgeois cultural prejudices. Walter Scott did so also, but in Catalonia the counterweight of a Byron, Larra or Manzoni did not exist, and so the necessary balance was missing. Nevertheless, the romantic spirit is the antithesis of seny; it is even identified with la rauxa ${ }^{5}$ and politico-cultural radicalism. We should not be surprised then that in the fourteenth century Francesc Eiximeni's, one of our medieval classics, wrote as if he were a good Jacobean:

D'aquí avant no hi haurà reys, ne duchs, ne comptes, ne grans senyors, ans d'aquí avant fins a la fi del món regnerà la justícia popular, e tot lo món per consegüent serà partit i regit per comunes. ${ }^{6}$

It could pass as the wild program of a twentieth century radical, and Ausias March himself, realizing his similar tendency, wrote, "Perdona mi si follament te parle". Neither could Llull be the pre-estevista model for the house-and-garden culture of the "Jocsfloralesque" literature. Ferran Soldevila has thus concluded that, although Catalans have been labeled practical and realistic, collectively they have always been idealists and Utopians. ${ }^{7}$ The disynchronization between Catalonia and the rest

${ }^{4}$ Lo catalanisme (Barcelona, 1888), second edition.

${ }^{5}$ We recommend reading the book by Rodolf Llorens, Com han estat $i$ com som els catalans (Barcelona: Ariel, 1963).

${ }^{6}$ Francesc Eiximenis, Regiment de Prínceps (1385).

${ }^{7}$ Ferran Soldevila, História de Catalunya (Barcelona: Selecta, 1977). 
of Spain also occurred at the Catalan national level between the official culture of the literary èlite, with their unitary and harmonious mythology, and that exemplified in the writing of $\mathrm{Ma}-$ ragall, face to face with the reality of life: "El fang dels teus carrers, oh Barcelona, / és pastat amb sang."

Therefore, Catalan national romanticism was, and possibly still is, fundamentally Utopian, both on the left and on the right. The bourgeois revolution of the nineteenth century failed miserably, ${ }^{8}$ precisely for not wanting to face reality and asking the impossible, as Gaziel - a man above suspicion - wrote:

El catalanisme burgès portava, però, una gravíssima contradicció interna: volia transformar radicalment a Espanya, sense que es produis ni la menor trencadissa material a Catalunya. I aquesta pretensió naturalment era utòpica.9

Modern Catalanism has also been leftist, especially anarchi$\mathrm{cal}$, and Utopian. From the Icarians at the beginning of the nineteenth century to the faistes of the Civil War, the anti-bourgeois Catalan intellectuals never abandoned the "road to Utopia". ${ }^{10}$ Let us remember the words of $\mathrm{Pi}$ i Margall in order to fully appreciate the modern Catalan way of being, totally permeated by Utopian romanticism: "La constitució d'una societat sense poder és l'última de les meves aspiracions revolucionàries". "I The most glorious moment of triumph was witnessed, fittingly, by an English writer:

${ }^{8}$ As, to be sure, one of its greatest literary describers makes clear; see Narcís Oller, La febre d'or.

9 Tots els camins duen a Roma: Història d'un destí (1893-1914) (Barcelona: s.d.), 293-301.

10 See the book by Josep Soler-Vidal, Pels camins d'Utopia (Mexico: Club del llibre català, 1958).

11 Francesc Pi i Margall, La reacción y la revolución (Madrid, 1854), 205. 
There was no unemployment... you saw very few conspicuously destitute people, and no beggars [Barcelona 1936]... Above all, there was a belief in the revolution and the future, a feeling of having suddenly emerged into an era of equality and freedom. ${ }^{12}$

Perhaps we should point out that it is among the most bourgeois peoples of Europe, such as the English and the Catalans, where the romantic-Utopian nostalgia for a less hectic and mechanized world occurs with greatest intensity and consistency. An Englishman of the seventeenth century, Thomas More, gave the name to this anarchical ideal, and another of the twentieth century, George Orwell, mystically experienced it in Catalonia: "...bound up with all my memories of that period... friendly crowds thronging the pavement to have a look at us, women waving from the windows." 13

But it was a Catalan novelist, Xavier Benguerel, who wrote the tragic chronicle of all these magnificent dreamers, these $\mathrm{Ca}$ talans of passion, who have wandered and who still wander throughout God's earth, searching romantically for a more just and humane place.

Icària, Icaria ${ }^{14}$ is the story of all these fools, daredevils, adventurers and even gun fighters, who are also part of the Catalan essence. Framed within three crucial dates (1848, 1922-23, 1936), this book tries to explain and justify the failure of an ethical and political movement founded on an excessive Utopianism which ended in excessive violence. Thus, Benguerel has touched the other chord, often forgotten, of the Catalan idiosyncracy. Icaria, Icaria is the perfect antidote for the bourgeois myth of senyor Esteve. From the North American adventure of a

${ }^{12}$ George Orwell, Homage to Catalonia (Boston: Beacon Press, 1967), 6.

13 Orwell, 14.

${ }^{14}$ (Barcelona: Planeta, 1974). We shall henceforth quote from this edition. 
group of Catalan followers of Étienne Cabet to the violence of the CNT and the FAI, and beyond the historical vicissitudes, the voice of Climent (one of the anarchists of this work) summarizes for us the perpetuity and the tragedy of the libertarian ideal:

"Un sonat com una cabra: era això aquest pare Cabet. Repliques indignat. És fals!... somiant haguessis trobat la bona manera d'explicar aquest sistema... sortir al carrer i fer un pregó per anunciar que la felicitat dels homes la portes dins del puny $i$ que no te la deixaràs pendre..." (I, I, 52).

Actually, Icària is like a paraphrase of Catalan nationalism, according to one of the central concepts of the German scholar Hans Magnus Enzensberger:

El nacionalismo catalán tiene dos caras. Su ala derecha representa los intereses de la burguesía regional y utiliza el problema de la autonomía para mistificar la lucha de clases. Pero para las masas la cuestión catalana adquiere un sentido enteramente revolucionario. ${ }^{15}$

The delirium of autonomy, the hatred of the power of a centralized state, and unlimited and total freedom drew Catalan workers to the search for a promised land in the Americas and finally to the disaster of 1936. But in spite of the setbacks and the disillusions, the messianic spirit of libertarian ideas, which Benguerel considers an inextricable part of the Catalan character, refused to die. Yes, house and garden, but also the mystical impulse of a free and unfettered people capable of heroic self-sacrifice:

No et dolguin sacrificis. El noi aviciat es plany: no puc més. En hores difícils, sempre es pot una mica més... I recorda-ho: hi ha d'haver, per força, un poble

${ }^{15}$ El corto verano de la anarquía (Barcelona: Grijalbo, 1972), 42. 
amb gent senzilla, pacifica i bona, m'entens, Climent... És injust no tenir temps per contemplar els arbres, el mar, per escoltar els ocells o veure passar els núvols... M'entens bé i a fons què vull dir? Sí, pare... - Endavant camarades! (272)

Icaria is thus a kind of Benguerelian homage to this free and heroic Catalonia of which Orwell wrote.

Lukács has said that the most fertile terrain for the historic novel is "a world in transformation", an "age of conflicts". ${ }^{16}$ These words appropiately apply to Icària which is the best critical chronicle of the Catalan anarchist movement. The novel has three temporal levels: a) the expedition of Catalans and other Icarians through lands in Texas and Illinois between 1848 and $1856,{ }^{17} \mathrm{~b}$ ) the armed union conflict at the beginning of the twentieth century, and c) the first days of the Civil War in Barcelona. It is worth mentioning that the temporal sequence of the work is not strictly linear, since there are moments when it is difficult to distinguish to which historical era certain acts and words belong, especially those which deal with the abstract consideration of anarchistical Utopia. For example, Climent reads

16 Translated from the German. See Georg Lukács, Der historiscbe Roman (Berlin, 1955).

17 The truly historical sources of this fictional novel are the book by Josep Soler-Vidal, Pels camins (see note 10) and the article by Jordi Ventura i Subirats, "Icaria", published in Cuadernos de Historia Económica de Cataluña, Vol. VII (Barcelona, s.d.), and, especially, Jules Prudhommeaux, Icarie et son Fondateur Etienne Cabet (Paris: Cornély, 1907). As an interesting aside, one may note that many of the descendents of these Icarian Catalans still live in the small town of Nauvoo in the state of Illinois (USA), which was where the Mormons sought refuge before arriving in Utah and also where the Mormon prophet Joseph Smith was assassinated. For the time of the armed violence of the turn of the century, the novelist tells us (288) that he has used the Memóries - unpublished - of his friend Miquel Ferrer. Otherwise, we must suppose that the personal experience of Benguerel himself is the primary source. 
the book of the Icarians in the 1920 's, but speaks as if it were 1848: "...si som incapaços de crear una Icària universal on sigui, és perquè ens hem convertit en miserables egoistes, en enemics dels nostres germans" (p. 93). It is not easy for the reader to know who is speaking or when. This technique emphasizes the eternal or atemporal element of the human libertarian instinct. On the other hand, the temporal structure is no longer ambiguous when the goal is to make clear the impossibility of this ideal: "La Veu de Catalunya -pàg. 9- Dimarts, 24 d'octubre de $1922 \ldots$.. 'Un policia $\mathrm{i}$ quatre anarquistes morts... quatre grups anarquistes per a atemptar contra el governador civil..." "(122). With this simple technique, Benguerel dramatizes the ideological and fatally tragic evolution of Cabet's Utopianism, based on the belief in the natural goodness of man, and what could be called the great disillusion of an entire generation who, from pacifist reformers, became revolutionaries: "Has viscut unes hores fora del món, del teu món... la memòria és història, penses" (270). The synthesis is perfect since the escape to faraway lands was part of the mystical deceit of some dreamers. The lesson is quite clear; it is not a question of escaping geography but history, and such an experience is inoperabe:

...a fora campava i dominava la mateixa casta que feia pensar a cops de tralla els esclaus, manaven els mateixos senyors feudals, els mateixos negrers. Els de sempre! (56)

Great faith produces great disappointment: "Al capdavall, allò va ser una pensada de cadell: l'illa no existia, Icària no existia, era inútil buscar-la" (56). From the noble savage of Rousseau we go to the human beast of Zola: "L'amor... entre les bèsties potser sí, però entre els homes...” (270), which consequently triggered the great outburst. In this novel, romantic Catalan idea- 
lism reveals itself in excessive extremes, from the mysticism of the brotherhood of man to the mysticism of violence:

Que s'ha de pelar el rei? Doncs, se'l pela i, llestos! Dic sí als Morral, als Mateu, als Nicolau, als qui van liquidar al tsar Alexandre, al rei d'Itàlia, i McKinley i Carnot i tants d'altres. (92)

Where is the oft-mentioned Catalan seny?

In Icària one goes from absolute Utopia to the most radical disappointment. It is a historical novel of intentions diametrically opposed to the epic mythification of the past. Actually, the "story of this story" has no meaning except as an instrument of conflict establishing parallels between two similar situations - past and present - and openly criticizing them. This type of novel can always be read on two levels. One is the novelized plot based on historical facts and true situations. ${ }^{18}$ Then, with perfect irony, one of the messages of the work is to preach the exercise of seny which has been so lacking in Catalan life during the last one hundred and fifty years. On another, more universal level, this counterpoint of present and past gives less synthetically dialectical results, since the human condition and civilization cannot survive without a certain transcendental hope ("tot és lleig, i trist, put a fanatisme, a discòrdia, a egoisme, a desig de venjar-se", 270). The great disillusion, in fact, is the great existential contradiction of reality and desire. Rovira himself, who died on the plains of Texas singing the Icarian Hymn of Great Hope, dies again, symbolically, while fighting in the streets of Barcelona in 1936:

...l'estrident explosió de la metralla... et cobreixes la cara amb les mans: se't xopen

18 See Biruté Ciplijauskaité, Los noventaochistas y la bistoria (Madrid: J. Porrúa Turanzas, 1981), 5. 
de sang, ni les veus, ni sents ja res més si no fos la consciència de tu mateix que se t'escapa igual que un crit feridor d'oreneta... Has caigut. (273)

Although desire is powerless within the realm of reality, the Roviras of the world continued to seek their absurd Jerusalem where, as Father Cabet said, "No bi baurà fallides ni sobresalts económics; no bi baurà plets ni passaports; esbirros ni gendarmes, ni botxins ni escarcellers" (59), and who continued dying and fighting for invisible and nonexistent El Dorados. The novel bites its own tail as do great literary works such as the Quixote and the Odyssey.

Great art always looks upward, not downward, and impassioned fools are the heroic prophets of humanity, the Captain Ahabs of the Hymn of Great Hope, the Jesuses of the Sermons on the Mount. Rovira's dying words are paradigmatic of the true anarchist prophet: "Endavant, camarades! Ens ho hem de guanyar a pols, no parar fins a destruir lo imatge d'un món que hem anat embrutant, envilint, entre tots... Endavant!” (272).

In this sense, this novel of sublime visionaries and dreamers is a relative anomaly within modern Catalan literature, which, to be sure, has begun to free itself from the mythology and bourgeois system of values of the Renaixença period. On the other hand, Catalan literary criticism is still slightly behind, since, with a few noteworthy exceptions, it has paid little attention to the work of Benguerel and others who have dared to go beyond the narrow, provincial view of Catalan culture.

Finally, Icària is emphatically neither and apology nor an anathema of the Catalan anarchist movement; it merely reports a historico-cultural event and incidentally indicates the danger as well as the pleasure of living passionately. However, Benguerel is one of "the last Mohicans" of a heroic era of "foguerades", as he himself has written more than once. Like Rovira in 
Icària and Pep Sisquelles in Gorra de plat, this writer is an unprofessed romantic who believes that "qui no fa res no pot ser res". ${ }^{19}$ Also, like his fictional creations, he combines the provincialism of a Barcelonese district (Poble nou, 1905) with the delirium of the Catalan wanderer. Forget seny and moderation; life is a road of uncertain glory:

Ja ho sé que tothom ho trobarà lamentable o incomprensible, però dintre meu persistia aquella vella dèria que m'exigia ser lliure, anar una mica a totes bandes, com el vent. (Gorra, 225)

Therefore we must meet life head on with a melancholy smile, before it escapes us "dins un túnel sense fi" (Icària, 274). This is possibly our greatest virtue as a people, to affirm, as do all Benguerel's characters, the world that we see, without prepossession and with reverence for this earthly existence. In spite of everything, as Salvat-Papasseit has told us, "La vida es una aventura que val la pena".

JOAN J. GILABERT THE UNIVERSITY OF ARIZONA

${ }^{19}$ Xavier Benguerel, Gorra de plat (Madrid-Barcelona: Alfaguara, 1967), 225. 